\title{
Enriching mothers' maths talk with their children through home visits
}

\author{
Ev ziyaretleri aracılı̆̆ıyla annelerin çocuklarıyla yaptıkları matematik \\ konuşmalarının zenginleştirilmesi \\ İrem Gürgah Oğul ${ }^{1}$, Yaşare Aktaş Arnas ${ }^{2}$, Şule Sarıbaş ${ }^{3}$
}

\begin{abstract}
Article History
Received :12 December 2019

Revised : 27 January 2020

Accepted : 18 February 2020
\end{abstract}

Article Type

Research Article

\begin{abstract}
Makale Geçmişi
Geliş : 12 Aralık 2019

Düzeltme : 27 Ocak 2020

Kabul : 18 Şubat 2020
\end{abstract}

Makale Türü

Arastırma Makalesi

\begin{abstract}
In this case study, it was examined the nature of mother's maths talk in the conversations with their children and the changes in mothers' maths talk in case of enriching the home maths environment through home based training activities. The naturalistic interactions between seven mothers and their preschool-aged children were recorded two times before and after the eight-week training activities. Training activities included the discussion sessions about children's maths development in early years and mothers' conducting maths activities with children in daily life. Findings from this research reveal that mothers' conversations with their children contain many words related to various mathematical skills. The research has also shown that some kinds of activities such as puzzle and cooking support the probability of emerging maths talk. Moreover, it was found that the amount and quality of mother's talk about mathematical concepts and skills increased after the home visits including training activities.
\end{abstract}

Keywords: Mathematics in early years, Home maths environment, Mother's maths talk, Home visits, Home-based training activities

Öz: Durum çalışması olarak desenlenen bu çalışmada, annelerin çocuklarıyla etkileşimlerinde kullandıkları matematik konuşmalarının doğası ve ev matematik çevresinin ev merkezli eğitim etkinlikleriyle zenginleştirildiği takdirde annelerin matematik konuşmalarındaki değişiklikler incelenmiştir. Yedi anne ve okul öncesi dönemdeki çocukları arasındaki doğal etkileşimler, sekiz haftalık eğitim etkinliklerinden önce ve sonra olmak üzere iki kez kaydedilmiştir. Eğitim etkinlikleri, çocukların erken dönemdeki matematik gelişimi ile ilgili tartışma oturumlarını ve annelerin çocuklarılla günlük yaşamlarında matematik etkinlikleri yürütmelerini içermektedir. Bu araştırmadan elde edilen bulgular, annelerin çocuklarıyla olan konuşmalarının, matematik becerileriyle ilgili birçok kelime içerdiğini ortaya koymaktadır. Araştırma, yapboz tamamlama, kek yapma gibi etkinliklerin matematik konuşmalarının gerçekleșme olasılığını desteklediğini de göstermiștir. Ayrıca, annenin matematik kavramları ve becerileri hakkında konuşma miktarının ve niteliğinin, eğitim etkinliklerini içeren ev ziyaretlerinden sonra arttığı bulunmuştur.

Anahtar Kelimeler: Okul öncesinde matematik, Ev matematik çevresi, Annelerin matematik konuşmaları, Ev ziyaretleri, Ev merkezli eğitim etkinlikleri 


\section{INTRODUCTION}

Early math skills are decisive in children's future academic achievements (Bailey, Siegler \& Geary, 2014; Duncan, Dowsett, Claessens, Magnuson, Huston, Klebanov \& Sexton, 2007). The opportunities for children around the home are important in the early period of development (Niklas \& Schneider, 2017). It has been demonstrated that mathematical activities conducted by parents with their children improve the mathematical skills of the latter (LeFevre, Skwarchuk, Smith-Chant, Fast, Kamawar \& Bisanz, 2009). Can we provide that parents give more emphasis on conversations related to children's maths skills during their interaction with their children?

It was revealed that the mathematics achievement of children differed from each other at the beginning of primary school (Sarama \& Clements, 2009). Moreover, the mathematical skills of children at different levels were related to the inputs they had received from their early ages (Blevins-Knabe \& Musun-Miller, 1996; Gunderson \& Levine, 2011; Klibanoff, Levine, Huttenlocher, Vasilyeva \& Hedges, 2006). Children involved in mathematical activities at young ages reflect positively on the success of the school they subsequently enter into.

The home maths environment is an important source of early maths inputs for children (Napoli \& Purpura, 2018). In this sense, families play an important role in the mathematical development of children (Anders et al., 2012; Kleemans, Peeters, Segers \& Verhoeven, 2012). For example, Kleemans et al. (2012) found in their study that activities at home conducted by parents with their children are effective in developing the early mathematics skills of children.

Parents use many concepts related to mathematics in their daily conversations with their children, with or without being aware of it. Children learn about many maths concepts in the early period through their interaction with their parents. They likewise learn from the informal experiences they faced in their home environment (Niklas \& Schneider, 2014). Parents have many opportunities to teach and experience mathematical concepts while doing everyday activities such as cooking, reading and shopping, among others (Vandermaas-Peeler, Boomgarden, Finn \& Pittard, 2012).

Research has established that the interaction of children with objects under the guidance of parents contributes to the development of their mathematics skills (Gunderson \& Levine, 2011; Levine, Ratliff, Huttenlocher \& Cannon, 2012; Siegler \& Ramani, 2009). For example, Gunderson and Levine (2011) found that parents who are helping their child understand objects within a group are actually aiding their child in learning the cardinal number principle. In another study by Levine et al. (2012), it was revealed that the frequency of talking about shapes and 
spatial characteristics of objects predicted the children's subsequent spatial thinking skills. However, mathematical conversations are different from one family to another (Levine, Suriyakham, Rowe, Huttenlocher \& Gunderson, 2010; Ramani, Rowe, Eason \& Leech, 2015). Ramani et al. (2015) examined the mothers with children aged 3 to 5 and found that mothers' activities with their children and their mathematics varied. Children are exposed to mathematics in their homes differently in terms of quality and quantity.

From this perspective, the role of families in the mathematical development of children is becoming more important. The opportunities that the family provides to the child in their home environment determine the nature of the inputs the child has. Children who are exposed to a large amount of maths talk at an early age can develop a better understanding of mathematics (Berkowitz et al., 2016). In this respect, the family should be aware of the importance of their roles and should be able to diversify the opportunities they provide to the child.

Many parents think that teaching mathematics is the responsibility of the school. In fact, they are unaware of their role in this subject towards their child (Cannon \& Ginsburg, 2008). However, the role of parents in their children's better understanding of mathematics is very significant. In this regard, parents should be encouraged to raise their awareness by providing them with concrete examples of how children learn mathematics in daily life (Cannon \& Ginsburg, 2008). Through this, children's experiences in learning maths at home can be enriched.

In the preschool period, children can learn many maths skills by applying mathematics in their daily lives (Gervasoni \& Perry, 2015; Kandır \& Orçan, 2010). During the day, children can work on concepts and skills such as patterns, shapes, spatial relationships, counting and comparing objects (Clements \& Sarama, 2007; Gürgah Oğul \& Aktaş Arnas, 2016). At home, families have the opportunity to support such early potential of their children (Niklas \& Schneider, 2014).

It is not possible to interfere with other certain characteristics of families. These include specific characteristics such as the socioeconomic level and educational status of the people making up the family. Accordingly, the development of the home maths environment should be seen as a priority because of the large contribution of the same to the development of the child's mathematics skills (Niklas, Cohrssen \& Tayler, 2016). Studies investigating the enrichment of the home maths environment (Berkowitz et al., 2016; Leung, Hernandez \& Suskind, 2020; Niklas et al., 2016; Starkey \& Klein, 2000) have demonstrated that trained families begin conducting activities with their children at home more frequently. To illustrate, Berkowitz et al. (2016) asked parents to provide their first grade children an activity involving the arrangement of a story time. Then, the parents asked their children verbal problems related to mathematics. Although the 
parents had maths anxiety, it was observed that the children's mathematical achievement increased by the end of the year. Similarly, in the study of Niklas et al. (2016), the families of 37 preschoolers aged approximately 4 years and 5 months were informed about the importance of the home maths environment. Individual interviews were held with the families about a maths game. The study found that even the non-intensive intervention they applied to families supported the home maths environment and improved the children's skills. Leung et al. (2020) implemented a six-month intervention programme involving children's cognitive and language skills for mothers who have children between 13 and 16 months. The said programme was performed through home visits. Their results suggested that mothers had more conversations with their children and asked more open-ended questions at the end of the programme.

There is a growing body of literature that recognises the significance of intervention to the home maths environment (Berkowitz et al., 2016; Niklas et al., 2016; Starkey \& Klein, 2000; Vandermaas-Peeler, Westerberg, Fleishman, Sands \& Mischka, 2018). However, little is known about parental practices related to mathematics. As such, the ways in which parents can improve their children's knowledge of mathematics remains unclear (Elliott \& Bachman, 2018). Therefore, intervention studies have not yet sufficiently demonstrated how the home environment can be made more effective in improving the child's mathematical competence. This study addresses the important points that may contribute to the literature on the mathematics activities of the parents at home. First, this study focuses on the home maths environment of children who did not participate in early childhood education. Previous studies (Berkowitz et al., 2016; Niklas et al., 2016) conducted with families of children attending an educational institution were successful in examining the children's mathematical development. However, it is important to also focus on the home environment of children who do not attend early childhood education institutions. This shall improve the quality of the factors that will have a potential impact on children's development. Second, considering the contribution of parents in the development of the child, increasing the number and quality of maths talk as the inputs provided by the mothers of these children was prioritised in this study. It is important to note that these involve children who are disadvantaged in terms of early childhood education. Indeed, the mathematics experiences of children at home determine the level of basic maths skills they will have (Anders et al., 2012; Blevins-Knabe \& Musun-Miller, 1996). Finally, such shall likewise create a prediction regarding the maths talk of mothers living in Turkey by studying with them in their natural environment. Information about conversations that arise during the interaction between the mother and child is usually based on the results obtained from self-reports of mothers (DeFlorio \& Beliakoff, 2015; Missall, Hojnoski, Caskie \& Repasky, 2015) or speech samples taken in structured 
environments (Ramani et al., 2015; Vandermaas-Peeler et al., 2012). Few studies (Gunderson \& Levine, 2011; Susperreguy \& Davis-Kean, 2016) examined the parent-child interaction naturally occurring at home. Besides, when there is insufficient information about the maths talk of mothers living in Turkey, this study may still contribute to the intervention studies for improving the quality and quantity of the inputs provided by mothers at home.

This study will scrutinise how mothers can support their children's mathematical development through home-based mother-training activities. The study examines the changes in the quality of mathematics conversations between mothers and their children. The following questions will be answered in the context of home visits to mothers:

1. Is there any change in the frequency of maths talk between mothers and their children?

2. What kind of change is there in the maths talk of mothers?

\section{METHOD}

\section{Research Design}

This study was designed as a case study, a qualitative research method. A case study requires a detailed exploration of a situation, event, or individual (Creswell, 2012). In this study, motherchild interactions supporting mathematics learning were discussed.

\section{Participants}

Seven children aged between 28 and 48 months ( $M=38$ months) who had not been participating in early childhood education were included in this study. Four children are girls and three are boys. The mothers of the children participating in the study are living in disadvantaged areas, including the middle and low socioeconomic status. The study group was determined using convenience sampling. Convenience sampling is a method used in research to prevent the loss of time, cost and labour (Büyüköztürk, Çakmak, Akgün, Karadeniz \& Demirel, 2011). The mothers in the study group were reached through fourth grade students in the preschool education department of a state university. Mothers were given information about the study process and those who were willing to participate in the study were included. Demographic information of the participant children's mothers and fathers is presented in Table 1.

Table 1. Demographic information of the participant children's mothers and fathers

\begin{tabular}{|c|c|c|c|c|}
\hline Participants & Parent & Age & Educational Level & Professional Status \\
\hline \multirow[t]{2}{*}{ Child 1} & Mother & 34 & Bachelor's degree & Officer \\
\hline & Father & 44 & Bachelor's degree & Unemployed \\
\hline Child 2 & Mother & 30 & Bachelor's degree & Unemployed \\
\hline
\end{tabular}




\begin{tabular}{lllll}
\hline \multirow{3}{*}{ Child 3 } & Father & 36 & Associate degree & Police officer \\
& Mother & 32 & Bachelor's degree & Teacher \\
Child 4 & Father & 34 & High school & Worker \\
& Mother & 28 & Primary school & Unemployed \\
Child 5 & Father & 33 & Middle school & Welder \\
& Mother & 38 & Associate degree & Officer \\
Child 6 & Father & 41 & Bachelor's degree & Worker \\
& Mother & 31 & High school & Unemployed \\
Child 7 & Father & 35 & High school & Plumber \\
& Mother & 32 & High school & Unemployed \\
& Father & 36 & High school & Fire fighter \\
\hline
\end{tabular}

As shown in Table 1, the age of the mothers of the children participating in the study varies between 28 and 38, while the age of their fathers ranges between 33 and 44 . Three of the mothers participating in the study have Bachelor's degrees and one has an associate degree. On the other hand, two mothers are high school graduates and one mother is a primary school graduate. Similarly, two of the fathers of the children have Bachelor's degrees and one has an associate degree. Three fathers are high school graduates and one is a middle school graduate. While most mothers are not working, two mothers work as officers and one as a teacher. One father is working as a police officer, two fathers as workers, one father as a welder, one father as a plumber, one father as a fire fighter and one father is not working.

\section{Data Collection}

The study was conducted based on home visits to the families of the participating children. Each family received weekly home visits, with a total of 11 visits. During the first home visit, mothers were informed about the study and they were asked information about the child and their family. On the second visit, mothers were asked to record an average of 20 minutes of voice during any activity spent with their children at home. Researchers and practitioners were not involved in the process of voice recording, so that the natural interaction between the mother and the child would not be affected by the presence of an unfamiliar person.

Mothers delivered recorded voice files to the practitioners. In the following period, the practitioners conducted home visits weekly and applied training activities which included mathematical concepts and skills to the mothers. Home visits, including training activities, lasted for eight weeks. After the training activities, at the last home visit, mothers were asked to take another 20 minutes of voice recording during any activity spent with their children. Researchers and practitioners were excluded in this process again. The two recordings were then taken from 
the mothers and were examined. The conversations between mother and child were transcribed after.

\section{Home Visits}

Each participant mother was visited at home for 11 weeks, one day a week. In eight of these visits, sessions were held with mothers regarding mathematical education activities at home. Each session focuses on a different mathematical skill. During the home visits, classification, comparison, ordering, one-to-one correspondence, numbers, operations (addition, subtraction), measuring, geometry and spatial perception and graphic skills were included. In some weeks, two skills are presented together. The skills that were presented to mothers during home visits were based on the maths skills that are expected to be gained by children in early years (Clements \& Sarama, 2014; Ministry of National Education [MEB], 2013). These sessions consist of two stages. In the first stage, the practitioner gave the mothers information about a mathematical skill and how this skill develops in children. The practitioner then talked about the sample activities. Unstructured activities related to skills were presented to the mothers. However, only exemplary activities at home that they are able to do with their children were mentioned. In the second stage, the practitioner expected from mothers to produce alternative activities that could contribute to the development of their children's mathematical skills. At the end of this interaction, the practitioner left the home. Until the other visit, mothers were asked to perform the alternative activities they had proposed with their children for one week. It was taken into account that these activities could be embedded in the daily activities of the children. Each home visit was scheduled like an assessment process for the mother. Here, the mother's implementation of the maths skill presented on the previous week and the presentation of a new maths skill for the upcoming week are looked into.

The data were collected from the mothers through seven pre-service early childhood teachers who were enrolled in early childhood education (ECE) programmes at a public university. They were selected among the seniors who volunteered to make home visits. These teachers had taken 'parent involvement', 'home-based education' and 'maths education in ECE' courses. These preservice teachers worked as practitioners in this study.

In this study, the researchers determined the mathematical skills to be presented to the mothers and the structure of the home visits. Researchers and practitioners held regular meetings every week and discussed how to make home visits. They likewise looked into which maths skills they would take and how they will enable mothers to produce maths activities. Later on, practitioners worked with the mothers through home visits. 


\section{Data Analysis}

According to the purpose of the study, voice recordings were taken during the natural conversations of the mothers with their children at home. This was done to detect maths talk at home. The obtained voice recordings were then transcribed. The data were analysed using content analysis and were subsequently reported.

The mothers were asked to record an average of 20 minutes of voice before and after the training activities. In the recordings, the mothers were requested to include naturalistic conversations at any time period they had spent with their children. A total of 223 minutes were obtained from the mothers. The length of the recordings ranged from $5 \min 5 \mathrm{sec}$ to $19 \min 32 \mathrm{sec}(M=15$ min) before the training activities. Conversely, the recordings ranged from $7 \mathrm{~min} 35 \mathrm{sec}$ to $21 \mathrm{~min}$ $13 \sec (M=17 \mathrm{~min})$ after the training activities.

The conversations recorded by the mothers were transcribed by one of the researchers. All spoken words by the mothers and children in voice the voice recordings were transcribed. The participants were given codes such as M1 (mother 1) and C1 (child 1). Moreover, the names of the participants were hidden. The researchers conducted a content analysis to analyse the conversations of the participants, thereby revealing their maths talk. While conducting content analysis, the paths of deductive analysis were followed. In the deductive analysis method, the data are analysed within the frame of a determined structure related to the subject (Patton, 2002). In this study, a coding scheme was determined in line with the codes used in the studies examining the maths talk. The data obtained from the participants were coded according to this coding scheme.

To ensure the validity and reliability of the study, some strategies suggested by Creswell (2012) and Patton (2002) were followed. While presenting the findings of the study, the data obtained from the participants were presented without any interpretation. Likewise, the sample statements of the participants were included, while explaining the coding. Moreover, the data obtained from the two mothers were analysed by the two researchers separately. To ensure the reliability of the coding, the frequencies of the mothers' maths talk were compared as a result of the coding conducted by the two researchers. In the inter-rater reliability calculations, the intra-class correlation coefficient (ICC) was used because of continuous variables (Shrout \& Fleiss, 1979). ICCs of the mothers' speeches taken before and after the activities were calculated. The reliability coefficient between the coders for the total speech of the mothers was .76. The degree of reliability was found to be satisfactory. A consensus has been reached with regard to the reliability of the coding. The data from the five other mothers were then coded by one of the researchers. 
In this process, the researchers continuously discussed to clarify the coding of the mathematical words. This prevented a researcher bias and ensured the reliability of the present study.

\section{Coding of maths talk}

While analysing the maths talk of mothers with their children, previous studies on maths talk (LeFevre et al., 2009; Susperreguy \& Davis-Kean, 2016) were examined. The mothers' talk with their children was coded in the context of preschool mathematics concepts and skills using a created coding scheme. The frequency of these statements was then reported. For example, when a mother says 'one, two, three', it is coded as counting. 'One' is coded similar to when it was used as a number word. If a statement expressed more than one mathematical concept or skill, the statement was separately coded for each mathematical concept and skill.

The nature of the mathematical conversations from the mothers was analysed on the basis of higher order instruction and basic skills instruction concepts proposed by Crosnoe et al. (2010). Susperreguy (2013) used these concepts as higher order maths talk and basic skills maths talk in her study to define the qualities of the maths conversations between preschool children and their mothers. In this study, higher order maths talk refers to making explanations and demonstrations about mathematical concepts and skills. Alternatively, basic skills maths talk refers to using mathematical concepts in a natural setting implicitly, without the intention of talking about mathematics. To illustrate, the mother's use of the words 'second' or 'third' only in her speech is called basic skills maths talk. Conversely, mothers explaining ordinal numbers such as 'third follows second' is described as a higher order maths talk (Susperreguy, 2013).

\section{RESULTS}

The results of the study are presented through three themes: the frequency of mathematical conversations between mothers and their children, the mothers' maths talk in the context of activities, and the quality of the mothers' maths talk with their children. While presenting the results, examples for the mothers' maths talk are provided to describe the mathematical concepts and skills.

\section{The Frequency of the Mathematical Conversations between Mothers and Their Children}

The researchers examined the voice recordings taken before the mothers' training activities. They then scrutinised the speeches of the mothers about mathematics. The researchers then determined the mathematical expressions used by the mothers in their daily activities with their children before and after the home visits. They likewise looked into how often these expressions were used by the mothers. 
Before the home visits on maths activities, the researchers observed that each mother used a different number of mathematical concepts related to the concepts of mathematics in their speeches. The number of mathematical expressions used by the mothers ranged between four (M6) and 93 (M5). The other mothers' conversation with their children included 25 (A2), 28 (A1), 38 (A4), 45 (A7) and 55 (A3), respectively. Table 2 provides an overview of the activities undertaken at home and the frequency of the mothers' mathematical talk at the recordings obtained before the training activities.

Table 2. The frequency of mothers' mathematical talk and the activities at the records obtained before the training activities

\begin{tabular}{|c|c|c|c|c|c|c|c|c|}
\hline Participants & M1 & M2 & M3 & M4 & M5 & M6 & M7 & \\
\hline Activities & 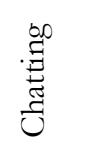 & 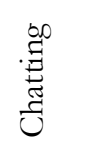 & 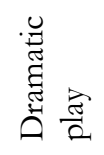 & 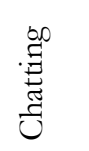 & 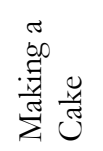 & 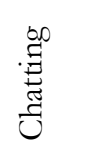 & 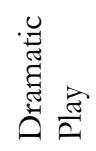 & $\begin{array}{l}\vec{\pi} \\
\stackrel{0}{0} \\
H\end{array}$ \\
\hline Comparing & 5 & 18 & 5 & 11 & 19 & 1 & 7 & 66 \\
\hline Spatial perception & 5 & 3 & 10 & 12 & 11 & 2 & 17 & 60 \\
\hline Time & 4 & 4 & 4 & 3 & 14 & 1 & 12 & 42 \\
\hline Counting & 11 & 0 & 4 & 11 & 3 & 0 & 1 & 32 \\
\hline Ordering & 2 & 0 & 4 & 1 & 21 & 0 & 1 & 29 \\
\hline Measuring & 0 & 0 & 1 & 0 & 25 & 0 & 1 & 27 \\
\hline Shapes & 0 & 0 & 17 & 0 & 0 & 0 & 0 & 17 \\
\hline Mathematical terms & 1 & 0 & 10 & 0 & 0 & 0 & 6 & 17 \\
\hline Matching & 0 & 0 & 1 & 0 & 0 & 0 & 0 & 1 \\
\hline Sorting & 0 & 0 & 0 & 0 & 0 & 0 & 0 & 0 \\
\hline Part \& Whole & 0 & 0 & 0 & 0 & 0 & 0 & 0 & 0 \\
\hline Operation (Adding) & 0 & 0 & 0 & 0 & 0 & 0 & 0 & 0 \\
\hline Total & 28 & 25 & 56 & 38 & 93 & 4 & 45 & 291 \\
\hline
\end{tabular}

Further analysis showed that the mothers used many concepts and words about mathematics in their daily lives with their children. When the first speech samples of the mothers were analysed, it was observed that conversations about comparing, spatial perception, time, counting, ordering, measuring, geometric shapes, mathematical terms and matching were present. The researchers found that the mothers engaged in spatial perception and comparison maths talk most frequently in the speech samples taken before home visits. This included educational activities as well. For example:

Mother (A3): Yes. What colour was it?

Child: Pink.

Mother: Yeah, there was a pink rabbit, right, on the cake? Let's do the same pie now. (spatial perception) (comparing)

Child: Yes, mommy. 
Moreover, it was revealed that the mothers often engaged in maths talk related to time in their conversations with their children. The researchers also found that counting was one of the mathematical skills that mothers frequently used while spending time with their children. Alternatively, the researchers heard only a few expressions related to ordering, measurement, geometric shapes and mathematical terms.

The researchers observed changes in the type and frequency of the mothers' maths talk in their conversations with their children after the home visits. In the speech samples obtained after the home visits and the maths sessions, the mothers engaged in more maths talk than the first speech examples. While the number of maths talk used by the mothers before the activity sessions was 291, the number of maths talk used after the maths activity sessions at home visits increased to 394. Table 3 provides the activities and frequencies of the mothers' maths talk with their children from the recordings obtained after the training activities.

Table 3. The frequency of mothers' mathematical talk and the activities at the records obtained after the training activities

\begin{tabular}{|c|c|c|c|c|c|c|c|c|}
\hline Participants & M1 & M2 & M3 & M4 & M5 & M6 & M7 & \\
\hline Activities & 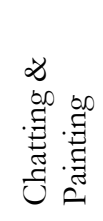 & 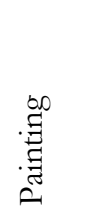 & $\begin{array}{l}\frac{u}{N} \\
\Xi \\
\Xi\end{array}$ & $\stackrel{\Xi}{\Sigma}$ & $\begin{array}{l}\text { 泀 } \\
0 \\
0 \\
000 \\
0 \\
0\end{array}$ & 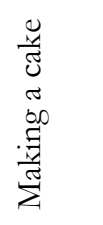 & 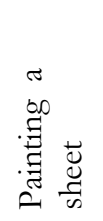 & 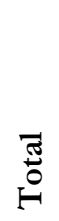 \\
\hline Comparing & 10 & 12 & 15 & 2 & 14 & 14 & 4 & 71 \\
\hline Time & 7 & 7 & 9 & 6 & 16 & 18 & 6 & 69 \\
\hline Counting & 7 & 0 & 9 & 0 & 29 & 17 & 1 & 63 \\
\hline Spatial perception & 14 & 1 & 29 & 0 & 16 & 0 & 0 & 60 \\
\hline Ordering & 0 & 0 & 3 & 1 & 7 & 3 & 2 & 45 \\
\hline Shapes & 0 & 12 & 0 & 0 & 19 & 12 & 0 & 43 \\
\hline Mathematical terms & 2 & 8 & 0 & 0 & 11 & 0 & 1 & 22 \\
\hline Measuring & 2 & 1 & 3 & 0 & 0 & 2 & 0 & 8 \\
\hline Classifying & 4 & 0 & 0 & 0 & 1 & 0 & 0 & 5 \\
\hline Parts \& Whole & 0 & 0 & 0 & 0 & 4 & 1 & 0 & 5 \\
\hline Operation (adding) & 0 & 0 & 3 & 0 & 0 & 0 & 0 & 3 \\
\hline Matching & 0 & 0 & 0 & 0 & 0 & 0 & 0 & 0 \\
\hline Total & 46 & 32 & 68 & 9 & 117 & 67 & 14 & 394 \\
\hline
\end{tabular}

Upon examining the recordings obtained from the mothers after the home visits, including the training activities, the researchers saw that the most frequent type of maths talk was counting. Mothers also used talks about time, as heard in the recordings obtained from the training activities. After comparing and time, the next most frequent types of maths talk were counting and spatial perception. Later, the mothers frequently engaged in interactions about ordering and shapes. 
Conversely, it was revealed that talks such as mathematical terms, measuring, parts and whole, classifying and operational skills were uncommon in the recordings of the mothers.

There are some remarkable points in the speech samples obtained after the training activities. The first one is that although the mothers did not talk about classifying, parts and whole and operations before the training activities, the speech samples taken after the training activities included a small number of talks about these mathematical concepts and skills. A second remarkable point in the speech samples of mothers after the training activities is that the frequency of measuring as a maths talk unexpectedly decreased.

\section{Mother's Maths Talk in the Context of Activities}

Upon examining the speech samples obtained before (first speech sample) and after (second speech sample) the home visits and the training activities of the mothers, the researchers observed that the mothers engaged in various activities with their children during the recordings. Table 2 and Table 3 present the activities that the mothers engaged with their children in the first and second recordings.

The results show that the maths talk involving certain mathematical concepts and skills was more common in some types of activities. In activities such as puzzle completion and cake-making, mothers have more mathematical conversations with their children. Conversely, some activities such as a structured painting activity limit the use of mathematical words in conversations between mother and child. For example, it was found that maths talk involving counting was used mostly in the speech samples taken during the activities of potato print-making and cake-making. Besides, a mother had the opportunity to use several spatial perception words than the other mothers while trying to complete a puzzle with her child.

Also, in the conversations recorded before the training sessions, the researchers observed that a mother (Mother 5) used measuring more than the other mothers during her cake-making activity. Similarly, another mother who was making cakes during the second recording engaged in conversations about time, including 'now' and 'one minute', more than the other mothers.

\section{The Quality of Mothers' Maths Talk with Their Children}

The researchers comparatively examined the speech samples obtained before the home visits, including the training activities, and after the training activities in terms of the quality of the participants' maths talk. Usually, there is basic skills maths talk in the mothers' conversations with their children. In fact, the mothers performed implicit mathematical conversations in the context of the activity during recordings. In other words, mothers used the maths concepts and skills 
mentioned above in their interactions without even having the intention of talking about mathematics in the first place.

The researchers likewise determined that none of the mothers used higher order maths talk in the conversations recorded before the training activities. All the conversations of the mothers with their children contained only basic skills maths talk before home visits. In the example of the speech taken before the training activities, the following conversations occurred while Mother 3 was chatting with her child:

Mother (M3): Yes. We are painting like your pastry, in this way. Let's make a rabbit with you?

Child (C3): Let's do it.

Mother (M3): How many ears did a rabbit have?

Child (C3): One, two, three, four.

Mother (M3): Are you sure?

Child (C3): Yes.

Mother (M3): It was two.

Child (C3): One, two, four. His feet were gone. I saw a couple of dogs on the way.

Mother (M3): Yeah, we just saw the dog while we were coming, right?

During this conversation, the mother (M3) used counting while performing a painting activity with her child. When the child said the numbers in the wrong order, the mother did not give any feedback to correct the mistake. However, the same mother gave a different answer in a similar case in the conversation recorded after the aforementioned training activities. The following dialogue occurred after the training activities:

Mother (M3): Look what was the name of this?

Child (C3): Basket.

Mother (M3): No, it was racket.

Child (C3): It was racket.

Mother (M3): Yes, it was.

Child (C3): One, two, four. That's how we counted.

Mother (M3): No, but after one comes two. What comes after two?

Child (C3): Ten.

Mother (M3): Three. 
Looking at the conversation after the training activities, the child said the numbers in the wrong order as in the previous recording. This time, however, the mother gave feedback to the wrong counting of the child. She caught the child's attention regarding the counting and explained the correct order of the numbers to the child. During this conversation, the mother engaged in a higher order maths talk with her child, with the intention of explaining counting. It can be observed that before the training activities, the mother's conversation with her child were coded as basic skills maths talk. On the other hand, the mother used higher order maths talk in a similar situation after the maths-training activities.

Another remarkable finding is that almost all the mothers engaged in interactions, including higher order maths talk after participating in the training activities. It must be noted that their mathematical conversations with their children already included basic skills maths talk before the training activities. The mothers used higher order maths talk about mathematical concepts and skills as heard from the conversations recorded after the training activities. As explained in the example above (M3), some mothers conducted a high level maths talk about counting.

The author observed that the mother (M6) had a higher level maths talk about rhythmic counting. This dialogue occurred as follows:

Mother (M6): Let's count up to ten?

Child (C6): Uh uh.

Mother (M6): Let's start.

Child (C6): one

Mother (M6): two

Child (C6): three four

Mother (M6): five

Child (C6): six seven

Mother (M6): Let's say it out loud, okay?

Child (C6): One

Mother (M6): One

Child (C6): Two

Mother (M6): Two

Child (C6): Three

Mother (M6): Three

Child (C6): What is this?

Mother (M6): Four. Then? Go ahead, count. 
Child (C6): One two three four five.

Mother (M6): Six, seven, eight, nine, ten.

It was revealed that another mother had higher order maths talk with her child to recognise numbers. The mother's (M5) higher order maths talk about recognising numbers while making puzzle with the child was as follows:

Mother (M5): Okay. Now you are going to put these, but the numbers.

Child (C5): This is the number.

Mother (M5): What number is this?

Child (C5): Five.

Mother (M5): This is half snake. Look, half snake.

Child (C5): Umm.

Mother (M5): Which number was the half snake? Three.

Child (C5): Three.

Mother (M5): But you should tell me the numbers while put on them. What comes after one?

Child (C5): One.

Mother (M5): After one?

Child (C5): Two.

Mother (M5): Yes, what is that number?

Child (C5): One.

Mother (M5): This is two, my girl.

Child (C5): Two.

The researchers likewise discovered that in addition to counting, the mothers had a higher order maths talk about comparing in the speech samples taken after the training activities. For example, a mother (M3) asked her child questions about the length of the objects. The mother also asked the child to compare the lengths with each other. The mother gave a higher order maths talk in this interaction, where she focused on the comparability of the objects in terms of lengths. The conversation between the mother and her child was as follows:

Mother (M3): Look here, we have two TV remote controls. We are going to play a short long game.

Child (C3): Um? 
Mother (M3): A short long game. Which of these controls is long, which is short?

Child (C3): This.

Mother (M3): What is this?

Child (C3): Short.

Mother (M3): Well done. And this one?

Child (C3): Long.

Mother (M3): Well done. Which one is long, this dog or this horse?

Child (C3): Horse.

Mother (M3): Is the horse long?

Child (C3): Yes

Mother (M3): Well done. Let's see. Anything else? So, which box is long and which one is short?

Child (C3): This one, this one, this is also short.

Mother (M3): They have the same length, don't they?

Child (C3): Yes.

After the home visits, where the mathematical training activities were discussed, the researchers found that the mothers performed higher order maths talk about geometric shapes as well. A mother (M6) asked her child questions about geometric shapes during cake-making and the following conversation was recorded:

Child (C6): Mommy, eggs are circles.

Mother (M6): Eggs are circles.

Child (C6): Like a ball.

Mother (M6): Like a ball.

Child (C6): They are rectangles.

Mother (M6): They are rectangles. But the eggs are not rectangles. What is rectangle, what do you think?

Child (C6): They are like teeth.

Mother (M6): Will the teeth be rectangles?

Child (C6): Yes.

Mother (M6): What shape do you think we have done?

Child (C6): Did we do circle? 
Mother (M6): Is the tray circle or square?

Child (C6): Square.

Mother (M6): Well done, you're so clever.

Similarly, a mother (M2) asked her child questions about geometric shapes and engaged in conversations using higher order maths. The conversation between the mother and her child was as follows:

Mother (M2): What colour should we paint the square?

Child (C2): Green.

Mother (M2): Green. It became very nice. What kind of shape is that?

Child (C2): Will we do colourful?

Mother (M2): What shape is this? What was the name of this shape?

Child (C2): A long square.

Mother (M2): What did we say about the long square?

Child (C2): Circle

Mother (M2): No, the circle becomes round. What did we call that? Think about it, and remember.

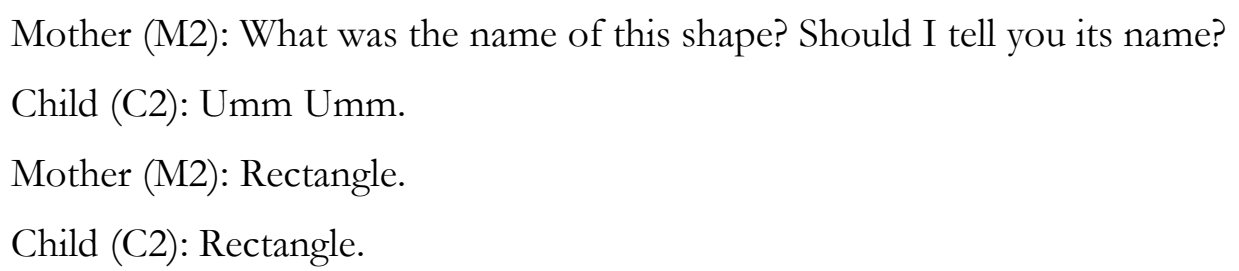

\section{CONCLUSION and DISCUSSION}

This research attempted to examine what kind of change occurs in the nature of the maths talk of mothers with their children through the home-based mother-training activities. The results of the study provided detailed information about the nature of their mathematical conversations at home and made significant contributions to literature. First, the most obvious finding to emerge from the analysis is that mothers use many mathematical concepts and skills such as comparing, spatial perception, time, counting, sorting, measurement, geometric shape, mathematical terms and matching in their conversations with their children. These results follow previous studies that have identified various types of mathematical conversations and terminologies in the home environment (Ramani et al., 2015; Tudge \& Doucet, 2004; Vandermaas-Peeler et al., 2018). Since mathematics 
is an integral part of daily life, children get the opportunity to participate in mathematical conversations and experiences while spending time with their families at home.

In addition, the author observed that the training given through home visits contributes more mathematical words. These words have been more frequently in activities performed between the mother and child, and the training activities reflected the conversations between them. Such can be explained by the raising of the awareness of the mothers on their role in the education of their children at the result of the training, learning the mathematical concepts and skills expected from the preschoolers, and taking emotional support as their children's educators. In the sessions during the home visits, the mathematics skills expected to be acquired in the preschool period were explained to the mothers. Mothers were expected to produce activities that could develop these skills, and they were asked to apply these activities at home with their children for a week. Mothers were assisted in producing these activities and emotional support was provided when they were discouraged. These informative studies and training activities also contributed to the increase in the awareness of the mothers about the developmentally appropriate mathematical concepts and skills for their preschool-aged children. Consistent with this finding, a study found that home-based family participation activities have a great impact on the development of children (Wheeler \& Conner, 2010). Another study shows that the quality of the learning environment at home and the participation of the parents in their children's education are more important than the socio-cultural status, income level and living conditions of the families and the parents' education level (Sylva, Melhuish, Sammon, Siraj-Blatchford \& Taggart, 2004). In this sense, it is an important for parents to be aware of their crucial role in their children's education. They should likewise work to increase their effort as educators of their children. The results of this study also confirm this argument.

Second, other activities such as puzzles and cake-making allow for certain types of maths talk to become more frequent. Alternatively, other activities such as a sheet painting activity limit the use of mathematical words in mother-child conversations. This finding broadly supports the study by Vandermaas-Peeler et al. (2018), who found that the types of activities influenced the manner by which the parents interacted with their children. For example, in the current study, a mother used more spatial perception words than other mothers during a puzzle game. Similarly, Levine et al. (2012) highlighted that the puzzle game increased the exposure of children to spatial expressions such as edges, corners, upper, lower, inner, outer and rotation. Alternatively, in this study, the mothers' expressions related to measuring were manifested just in the food preparation (cakemaking) activity. Similar to the present results, a previous study has also demonstrated that cooking activities create a more favourable environment for experiencing mathematical skills 
(Vandermaas-Peeler et al., 2018). Activities such as puzzles and cooking naturally inspire mathematical interactions. Also, another finding obtained from the present study showed that the total frequency of the talks about measuring decreased in the mothers' speeches recorded after the activities. Parents often focus more on numeracy activities at home and engage less often in non-numeracy activities (Zippert \& Rittle-Johnson, 2020). In this study, the mothers may have used fewer expressions about measurement in the activities, as they focused on activities involving less complex skills. This is the result of the current study that some activities limit the probability of the occurrence of mathematical words, while some of them encourage the mothers to talk about maths.

Another important finding was that the training activities given at home were reflected in the quality of the mathematical conversations. While there was no higher order maths talk between the mother and children before the home-based training activities, the researchers found that the mothers talked about higher order maths during the mother-child interactions recorded after the training activities. After the eight-week home-based sessions, including the discussion between mothers and practitioners about how they can teach maths to the children and which activities contribute to the children's maths development, the mothers used more words related to higher order maths talks. This result may be brought about by the mothers' exploration of opportunities to explain mathematics to their children after learning new ways on how to teach mathematics. Additionally, mothers may have had the opportunity to make inferences about the level of their children's knowledge during the home activities. In many previous studies (LeFevre et al., 2009; LeFevre, Polyzoi, Skwarchuk, Fast \& Sowinski, 2010; Starkey \& Klein, 2000; Vandermaas-Peeler et al., 2018), the children of the mothers who engage in home maths activities frequently have high maths skills. This study aimed to encourage mothers to use mathematics in their daily routines with their children. Accordingly, it is expected that the activities that mothers had engaged in with their children contributed to the latter's knowledge of mathematics. As such, the mothers' expectations from their children may also have increased. Parents who have high expectations of maths achievement from their children engage in more advanced maths activities with them (Skwarchuk, Sowinski \& LeFevre, 2014). Studies (Del Río, Susperreguy, Strasser \& Salinas, 2017; Skwarchuk et al., 2014) suggest that the mothers' expectations for learning mathematics are related to the maths activities they perform at home. Discussions with the mothers during home visits may have positively reflected on the mothers' expectations from their children regarding learning mathematics. In a study by Karslı and Allexsaht-Snider (2015) to reveal parents' ideas about the mathematical learning of children outside the school, the parents stated that they realised that mathematics was involved in various activities during daily life. 
However, it has not been discovered how parents have translated these activities into mathematical learning opportunities. This study provides examples of how the mothers' daily experiences are being transformed into mathematical learning opportunities for their children by using higher order maths talk in their daily activities.

Cannon and Ginsburg (2008) revealed that most mothers did not have an idea about what their child should know about mathematics in the preschool period. In the current study, through home visits for eight weeks, information about the mathematical skills expected from children to achieve are presented to the mothers. Moreover, the mothers were asked to produce activities that could integrate this information with the daily life to allow their children to develop a deeper understanding of their mathematical skills. Evans, Fox, Cremaso and McKinnon (2004) found that mothers believed that the preschool had a primary role in the development of preschoolers' mathematical skills. However, the results of this study showed that the training activities through home visits contributed to the children's home maths environment even with the increase in the number and quality of the mothers' maths talk. In fact, Niklas et al. (2016) explained that even an informative meeting with mothers increased the quality of the home learning environment.

This study provided a wealth of information in exploring the nature of children's mathematical understanding. Such was achieved by interfering with the home maths environment in the context of parent-child interactions. After home visits, the mothers' speeches, including mathematical concepts and skills have mostly increased. Additionally, the researchers found that mothers started to talk about higher order mathematics in their daily life after participating in training activities. In this context, to provide children a rich maths environment both quantitatively and qualitatively, parents should be trained about how they can enrich the home maths environment. They should likewise be more aware of their role as educators. Parents should also be encouraged to use materials or activities that can facilitate mathematical interactions.

The results of this study make several contributions to the current literature. However, this study also has some limitations. First, it is unfortunate that the study included only mothers and mother-child interactions examined in terms of home mathematics. A further study could examine the process involving also fathers. Also, in this study, mothers were given information about mathematical concepts and skills. After these sessions, mothers were asked to produce mathematical activities themselves. The mothers then applied these activities with their children in their daily life. Further research could also be conducted to reveal the reflections of the structured activities that were presented to mothers on a home maths environment. 
Moreover, the length of the recordings of the mothers' interaction with their children during their daily activities was limited to an average of only 20 minutes. Nevertheless, some mothers did not meet the desired time and recorded even shorter speech samples. To make more comprehensive inferences in future studies, longer speech samples should be taken from mothers. The option of covering a few days of activities may likewise be considered. In addition, training activities with the mothers was conducted for eight weeks in the current study. In further studies, training activities may be conducted for longer periods of time.

All the findings obtained from the study emphasise that the informing the mothers about the mathematics education of their children, encouraging them to organise mathematical activities that can provide more permanent learning to their children, and making them more aware of their role as educators will provide these mothers with the unique opportunities to learn and aid in their children's mathematics development. With this aspect, the current study revealed the importance of increasing parental awareness in supporting the child's mathematical development during home activities.

\section{REFERENCES}

Anders, Y., Rossbach, H. G., Weinert, S., Ebert, S., Kuger, S., Lehrl, S., \& von Maurice, J. (2012). Home and preschool learning environments and their relations to the development of early numeracy skills. Early Childhood Research Quarterly, 27(2), 231-244. doi:10.1016/j.ecresq.2011.08.003

Bailey, D. H., Siegler, R. S., \& Geary, D. C. (2014). Early predictors of middle school fraction knowledge. Developmental Science, 17(5), 775-785.

Berkowitz, T., Schaeffer, M. W., Maloney, E. A., Peterson, L., Gregor, C., Levine, S. C., \& Beilock, S. L. (2016). Math at home adds up to achievement in school. Science, 350(6257), 196-198. doi: 10.1126/science.aac7427.

Blevins-Knabe, B., \& Musun-Miller, L. (1996). Number use at home by children and their parents and its relationship to early mathematical performance. Early Development and Parenting: An International Journal of Research and Practice, 5(1), 35-45.

Büyüköztürk, Ş., Çakmak E. K., Akgün Ö. E., Karadeniz Ş., \& Demirel F. (2011). Bilimsel araștırma yöntemleri [Scientific Research Methods](8th ed.). Ankara: Pegem Akademi.

Cannon, J., \& Ginsburg, H. P. (2008). "Doing the math": Maternal beliefs about early mathematics versus language learning. Early Education and Development, 19(2), 238-260. doi: 10.1080/10409280801963913. 
Clements, D. H., \& Sarama, J. (2007). Early childhood mathematics learning. In F. K. Lester Jr., (Ed., Vol. 1). Second handbook of research on mathematics teaching and learning, (pp. 461-555). New York, NY: Information Age Publishing.

Clements, D. H., \& Sarama, J. (2014). Learning and teaching early math: The learning trajectories approach. (2nd ed.). New York, NY: Routledge.

Creswell, J. W. (2012). Educational research: Planning, conducting, and evaluating quantitative and qualitative research (4th ed.). Boston, MA: Pearson.

Crosnoe, R., Morrison, F., Burchinal, M., Pianta, R., Keating, D., Friedman, S. L., ... Human Development Early Child Care Research, N. (2010). Instruction, teacher-student relations, and math achievement trajectories in elementary school. Journal of Educational Psychology, 102(2), 407-417. doi: 10.1037/a0017762.

DeFlorio, L., \& Beliakoff, A. (2015). Socioeconomic status and preschoolers' mathematical knowledge: The contribution of home activities and parent beliefs. Early Education and Development, 26(3), 319-341. doi: 10.1080/10409289.2015.968239.

Del Río, M. F., Susperreguy, M. I., Strasser, K, \& Salinas, V. (2017). Distinct influences of mothers and fathers on kindergartners' numeracy performance: The role of math anxiety, home numeracy practices, and numeracy expectations. Early Education and Development, 28(8), 939-955.

Duncan, G. J., Dowsett, C. J., Claessens, A., Magnuson, K., Huston, A. C., Klebanov, P., \& Sexton, H. (2007). School readiness and later achievement. Developmental Psychology, 43(6), 1428-1446. doi: 10.1037/0012-1649.43.6.1428.

Elliott, L., \& Bachman, H. J. (2018). How do parents foster young children's math skills?. Child Development Perspectives, 12(1), 16-21. doi: 10.1111/cdep.12249.

Evans, M. A., Fox, M., Cremaso, L. \& McKinnon, L. (2004). Beginning reading: The views of parents and teachers of young children. Journal of Educational Psychology, 96(1), 130-141. doi: 10.1037/0022-0663.96.1.130.

Gervasoni, A., \& Perry, B. (2015). Children's mathematical knowledge prior to starting school and implications for transition. In B. Perry, A. MacDonald, \& A. Gervasoni (Eds.), Mathematics and transitions to school: International perspectives (pp. 47-64). Dordrecht: Springer.

Gunderson, E. A., \& Levine, S. C. (2011). Some types of parent number talk count more than others: relations between parents' input and children's cardinal-number knowledge. Developmental Science, 14(5), 1021-1032.

Gürgah Oğul, İ., \& Aktaş Arnas, Y. (2016). Preschool children's mathematical experiences in outdoor play. In R. Efe, İ. Koleva, E. Atasoy, \& İ. Cürebal (Eds.), Developments in educational sciences (pp. 196-207). Sofia: St. Kliment Ohridski University Press.

Kandır, A., \& Orçan, M. (2010). Okul öncesi dönemde matematik eğitimi [Mathematics Education in Early Childhood]. İstanbul: Morpa Kültür Yayınları.

Karsl1, E., \& Allexsaht-Snider, M. (2015). Video-cued parental dialogs: A promising venue for exploring early childhood mathematics. Education and Science, 40(179). doi: 10.15390/EB.2015.4227. 
Kleemans, T., Peeters, M., Segers, E., \& Verhoeven, L. (2012). Child and home predictors of early numeracy skills in kindergarten. Early Childhood Research Quarterly, 27(3), 471-477. doi: 10.1016/j.ecresq.2011.12.004.

Klibanoff, R. S., Levine, S. C., Huttenlocher, J., Vasilyeva, M., \& Hedges, L. V. (2006). Preschool children's mathematical knowledge: The effect of teacher "math talk". Developmental Psychology, 42(1), 59-69. doi: 10.1037/0012-1649.42.1.59.

LeFevre, J., Skwarchuk, S.-L., Smith-Chant, B. L., Fast, L., Kamawar, D., \& Bisanz, J. (2009). Home numeracy experiences and children's math performance in the early school years. Canadian Journal of Behavioural Science, 41(2), 55-66. doi: 10.1037/a0014532.

LeFevre, J., Polyzoi, E.,Skwarchuk, S., Fast, L., \& Sowinski, C. (2010). Do home numeracy and literacy practices of Greek and Canadian parents predict the numeracy skills of kindergarten children? International Journal of Early Years Education, 18(1),55-70. doi.org/10.1080/09669761003693926.

Leung, C. Y., Hernandez, M. W., \& Suskind, D. L. (2020). Enriching home language environment among families from low-SES backgrounds: A randomized controlled trial of a home visiting curriculum. Early Childhood Research Quarterly, 50(1), 24-35.

Levine, S. C., Suriyakham, L. W., Rowe, M. L., Huttenlocher, J., \& Gunderson, E. A. (2010). What counts in the development of young children's number knowledge?. Developmental Psychology, 46(5), 1309-1319.

Levine, S. C., Ratliff, K. R., Huttenlocher, J., \& Cannon, J. (2012). Early puzzle play: a predictor of preschoolers' spatial transformation skill. Developmental Psychology, 48(2), 530-542. doi: $10.1037 / \mathrm{a} 0025913$.

Milli Eğitim Bakanlığ1 [MEB] (2013). Okul öncesi eğitim programı. Retrieved February 8, 2020, from https://tegm.meb.gov.tr/dosya/okuloncesi/ooproram.pdf.

Missall, K., Hojnoski, R. L., Caskie, G. I., \& Repasky, P. (2015). Home numeracy environments of preschoolers: Examining relations among mathematical activities, parent mathematical beliefs, and early mathematical skills. Early Education and Development, 26(3), 356-376.

Napoli, A. R., \& Purpura, D. J. (2018). The home literacy and numeracy environment in preschool: Cross-domain relations of parent-child practices and child outcomes. Journal of Experimental Child Psychology, 166(2), 581-603. doi: 10.1016/j.jecp.2017.10.002.

Niklas, F., \& Schneider, W. (2014). Casting the die before the die is cast: The importance of the home numeracy environment for preschool children. European Journal of Psychology of Education, 29(3), 327-345. doi: 10.1007/s10212-013-0201-6.

Niklas, F., \& Schneider, W. (2017). Home learning environment and development of child competencies from kindergarten until the end of elementary school. Contemporary Educational Psychology, 49(2), 263-274. doi: 10.1016/j.cedpsych.2017.03.006.

Niklas, F., Cohrssen, C., \& Tayler, C. (2016). Improving preschoolers' numerical abilities by enhancing the home numeracy environment. Early Education and Development, 27(3) 1-12. doi: 10.1080/10409289.2015.1076676. 
Patton, M. Q. (2002). Qualitative evaluation and research methods. (3rd ed.). London: Sage Publications.

Ramani, G. B., Rowe, M. L., Eason, S. H., \& Leech, K. A. (2015). Math talk during informal learning activities in Head Start families. Cognitive Development, 35(3), 15-33. doi: 10.1016/j.cogdev.2014.11.002.

Sarama, J., \& Clements, D. H. (2009). Early childhood mathematics education research: Learning trajectories for young children. New York, NY: Routledge. doi: 10.4324/9780203883785.

Shrout, P. E., \& Fleiss, J. L. (1979). Intraclass correlations: Uses in assessing rater reliability. Psychological Bulletin, 86(2), 420-428.

Siegler, R. S., \& Ramani, G. B. (2009). Playing linear number board games-but not circular ones-improves low-income preschoolers' numerical understanding. Journal of Educational Psychology, 101(3), 545-560. doi: 10.1037/a0014239.

Skwarchuk, S. L., Sowinski, C., \& LeFevre, J. A. (2014). Formal and informal home learning activities in relation to children's early numeracy and literacy skills: The development of a home numeracy model. Journal of Experimental Child Psychology, 121(5), 63-84.

Starkey, P., \& Klein, A. (2000). Fostering parental support for children's mathematical development: An intervention with Head Start families. Early Education and Development, 11(5), 659-680. doi: 10.1207/s15566935eed1105_7.

Susperreguy, M. I., \& Davis-Kean, P. E. (2016). Maternal math talk in the home and math skills in preschool children. Early Education and Development, 27(6), 841-857. doi:10.1080/10409289.2016.1148480.

Susperreguy, M. I. (2013). "Math talk" in families of preschool-aged children: Frequency and relations to children's early math skills across time. Unpublished doctoral dissertation, University of Michigan, Michigan.

Sylva, K., Melhuish, E., Sammons, P., Siraj-Blatchford, I., \& Taggart, B. (2004). Effective preschool provision. London: Institute of Education.

Tudge, J. R., \& Doucet, F. (2004). Early mathematical experiences: Observing young Black and White children's everyday activities. Early Childhood Research Quarterly, 19(1), 21-39. doi:10.1016/j.ecresq.2004.01.007.

Vandermaas-Peeler, M., Boomgarden, E., Finn, L., \& Pittard, C. (2012). Parental support of numeracy during a cooking activity with four-year-olds. International Journal of Early Years Education, 20(1), 78-93. doi: 10.1080/09669760.2012.663237.

Vandermaas-Peeler, M., Westerberg, L., Fleishman, H., Sands, K., \& Mischka, M. (2018). Parental guidance of young children's mathematics and scientific inquiry in games, cooking, and nature activities. International Journal of Early Years Education, 26(4), 369-386. doi: 10.1080/09669760.2018.1481734.

Wheeler, H. \& Conner, J. (2010). Parents, early years and learning. London: National Children's $\begin{array}{lllll}\text { Bureau. } & \text { Retrieved } & \text { May } & \text { 2019, from }\end{array}$ 
https://www.ncb.org.uk/sites/default/files/uploads/documents/Early_years_docs/Acti vities_bookletV3_LoRes.pdf.

Zippert, E. L. \& Rittle-Johnson, B. (2020). The home math environment: More than numeracy. Early Childhood Research Quarterly, 50(3), 4-15. 